\title{
A Study of the Market Failure in the Financing of High-Tech SMEs and the Governmental Intervention
}

\author{
Miaobing Liu \\ Institute of Industrial Economics, Jinan University, Guangzhou, China \\ Email: 752449872@qq.com
}

Received 29 February 2016; accepted 21 March 2016; published 24 March 2016

Copyright (C) 2016 by author and Scientific Research Publishing Inc.

This work is licensed under the Creative Commons Attribution International License (CC BY). http://creativecommons.org/licenses/by/4.0/

(c) (i) Open Access

\begin{abstract}
With the progress of the society, the High-tech SMEs play a more and more important role in the development and innovation of a country. However, the financing of the High-tech SMEs faces a serious market failure, and the government has to intervene. Based on this, this article analyzes the root which leads to the market failure in the financing of High-tech SMEs from three aspects: serious uncertainty, information asymmetry and externality, and puts forward the concrete policy measures of government intervention and discusses the government failure that exists in the process of governmental intervention. Finally, on the basis of above analysis, this paper puts forward some appropriate policy recommendations.
\end{abstract}

\section{Keywords}

High-Tech SMEs, Finance, Market Failure, Governmental Intervention, Government Failure

\section{Introduction}

Science and technology has been the first productive force, and the high-tech enterprises gradually become a rather important power of contemporary economic development. The practice of some developed countries over the past years also shows the key role which the high-tech enterprises play in sustainable economic growth and innovation of a country [1]. Mason (2009) pointed out that small and medium-sized high-tech enterprises were the main source of innovation, creating employment and productivity growth [2].

In general, the development of high-tech enterprises can be divided into four stages, namely seed period, start-up period, expanding period and mature period. In the seed period and start-up period, high-tech enterprises generally have a higher risk, and considering the lack of collateral and track record, it is difficult for them to ob- 
tain financing from traditional sources, such as banks. A large number of studies have shown that the funds and service from VC (venture capital) can be a huge promotion to the growth of High-tech SMEs [3]-[5]. However, VC is more inclined to investing in expanding period and mature period of High-tech SEMs, and relatively less support in seed period and start-up period. And, even if there is a support from VC, it is woefully inadequate. Undoubtedly, this will severely hinder the early development of High-tech SMEs. For this reason, the governments launch many programs to solve the problem of shortage of VC investing in High-tech SMEs by using their "visible hands". These programs include SBIR project of America, YOZMA project of Israel, IIF and PSF project of Australia, LSVCC fund of Canada, and Torch project, SMEs Technology Innovation Fund and subsequent Government-guiding fund of China, etc.

Therefore in this article, the second part mainly discusses the theoretical basis of governmental intervention to VC investing in High-tech SMEs from three aspects: serious uncertainty, information asymmetry and externality; The third part summarizes the tools of governmental intervention to the financing of High-tech SMEs; The fourth part analyzes the problem of government failure appearing in the governmental intervention; The last part gives some appropriate policy recommendations.

\section{The Theoretical Basis of Governmental Intervention to the High-Tech SMEs' Financing}

The theme about the difficulty of High-tech SMEs' financing has been the research focus for many years by multitudinous scholars. The scholars at home and abroad have discussed the root why governments intervene the activity of VC. Summing up the research of many scholars, the theoretical basis of governmental intervention to VC investing in High-tech SMEs can be divided into three aspects: serious uncertainty, information asymmetry and externality.

\subsection{Serious Uncertainty}

High-tech enterprises are the aggregations which combine high risk and high yield, especially for those during seed period and start-up period, and generally they are still in the stage of investing when fund is urgently needed, but they have no profits and favorable track record to support them to reach to the financing from traditional sources, such as banks. Meanwhile, in the process of developing, they will face more unpredictable risk because of products' immaturity and changes in the national industrial policy. Therefore, high-tech enterprises will encounter more obstacles in the process of financing, so it is important for government to intervene and hatch in order to ease the funding problems.

\subsection{Information Asymmetry}

Governments need intervene the activity of VC, not only because of VC's promotion to the development of social economy (such as enterprise value, innovation, the competitiveness of the economy and social entrepreneurship, employment, etc.), but also due to the market failure caused by asymmetric information between market players.

High-tech SMEs face serious information asymmetry. Although the VC can reduce the information asymmetry through venture capitalists' expertise and due diligence to some extent, this information asymmetry can not be completely eliminated. No matter what kind of organization forms of venture investment funds, venture capitalis likely to be subjected to entrepreneur's moral hazard problem of two kinds: One is the ex ant moral hazard discussed by Jensen \& Meckling (1976) [6]. This kind moral hazard involves a kind of management action that can not transfer or difficult to transfer, but entrepreneurs can choose them, such as private benefits or effort level. In fact, it is also a important variable used frequently in classical moral hazard model. Normally, it is impossible to contract. The other is the ex post moral hazard discussed by Aghion \& Bolton (1992) [7]. This kind moral hazard involves a kind of management action that is impossible to contract, but the right of decisionmaking is transferable or can be transferred more easily, such as the decision about whether to replace the CEO, to retain or liquidation enterprise. Investors and entrepreneurs can make such a decision.

\subsection{Externality}

High-tech enterprises belong to the knowledge-intensive enterprises, and the main output of its R\&D investment 
and innovation activities is the knowledge which can create new products and services, but this knowledge is not exclusive to others, so the innovative product is easily imitated and replicated by competitors. Arrow (1962) pointed out the confidentiality of innovations is rather poor, so the return of investment can not be proportional to the amount of investment by enterprise. Therefore, these enterprises are reluctant to invest, leading to the lack of investment to technology innovation in the economy [8]. Gompers \& Lerner (2001 a) also put forward that the innovation returns can not be completely internalized by innovative enterprise, so it leads to the VC's social rate of return higher than the VC's private rate of return, causing the market failure of lacking VC investment [4]. Interests are not fully possessed by innovators, so to some extent governmental intervention is required to make up for the loss of innovative enterprise caused by external effects and ease the market failure problem of insufficient VC investment.

\section{The Ways of Governmental Intervention in the Financing of High-Tech SMEs}

Since the serious problem of market failure exits in the finance market of High-tech SMEs, relying solely on market forces can not be a good solution to the problem of capital allocation. This means it is necessary for government to use its "visible hand" to intervene. The way of governmental intervention in the finance of High-tech SMEs is diverse, but there are four main ways: 1) Fund support; 2) Tax policy; 3) Financial subsidy; 4) Infrastructure construction of investment environment.

\subsection{Fund Support}

Fund support is the most direct way to alleviate the financing problems of High-tech SMEs. Fund support can be divided into direct fund support and indirect fund support.

Direct government fund support is such a kind of support: The government funds the establishment of a state-owned venture investment institution and this state-owned institution gives direct investment to high-tech enterprises. Government venture investment fund of China are all in this form from 1985 to 2008, as well as part of funds in Israeli YOZMA project. Direct government fund support can increase the supply of venture capital funds. Meanwhile, the government can limit the fund to the specific investment object, investment area and investment stage, thereby increasing the fund supply of economically underdeveloped areas and the early periods of high-tech enterprises (early periods means seed period and start-up period), thus giving an adequate relief of their market failures.

The state-owned venture capital institution which is established by government, can do make up for the lack of VC investment caused by market failure to some extent. But the government money is limited, and there exists many problems during the operation of direct government fund support, such as insufficient incentive of managers, the lack of professional knowledge and rent-seeking behavior, so indirect government fund support is necessary. Indirect government fund support is such a kind of support: The government founds the government-guided venture investment fund by putting into a certain number of fiscal funds. Such a certain number of fiscal funds play a role of seed fund which aims to attract other types of social capital. So it will guide social capital into venture investment area, providing indirectly more financial support for high-tech enterprises. Indirect government fund support can bring the government function into play in compensating for the lack of VC investment caused by market failure as well as direct fund support, but the former one has more advantages.

\subsection{Tax Policy}

Tax policy is another effective means of government intervention. Among these policies, one kind is aimed at the tax incentives for venture investment enterprises, such as low capital gains tax; Another kind is tax incentives for high-tech enterprises, such as tax breaks for high-tech park enterprises, etc.

Tax incentives for venture investment enterprises such as low capital gains tax, can reduce the cost of VC investment and increase VCs' motivation of investing in high-tech enterprises, thereby alleviating the shortage of investment to high-tech start-ups caused by market failure to a certain extent. According to related papers, the most profitable ways to exit from high quality high-tech start-ups are IPO and acquisition. The gains from exiting through IPO and acquisition are closely related with capital gains tax [3] [9] [10], so the capital gains tax is very important for the high-tech start-ups to get the financing from VC. As the US capital gains tax fell from 35\% in 1977 to 20\% in 1982, the VC financing increased from \$68.2 million in 1977 to \$2.1 billion in 1982. 
Tax incentives for high-tech enterprises play a decisive role in the development of High-tech SMEs. Zhou Lu (2011) pointed out that tax incentives reduce the burden of High-tech SMEs to some extent and strengthen its ability to resist risks. The studies of Grubert and Mutti (1991), Swenson (1994) and Hines (1996) confirm that the tax incentives for start-up enterprises help them receive financial support [11]-[13].

\subsection{Financial Subsidy}

According to different objects of subsidy, the government financial subsidy for the financing of High-tech SMEs can be divided into two ways: One is the subsidy for High-tech SMEs; Another one is the subsidy for venture investment enterprises

Government subsidy for the High-tech SMEs can internalize the externality of High-tech SMEs and will help to reduce the uncertainty of High-tech SMEs. Specific subsidies include scientific research allowance, government procurement and government guarantee, etc. For example, scientific research allowance can reduce the risk of loss coming from R\&D activities, and then reduce the uncertainty of High-tech SMEs; Government guarantee will help alleviate the difficulty of financing from traditional financing sources, and it also helps to reduce the investment risk of investors, therefore increasing the capital supply towards start-up high-tech enterprises.

Government subsidy for the venture investment enterprises can reduce the investment risk of venture investment enterprises, and will guide them to invest in High-tech SMEs, therefore increasing the VC supply towards start-up high-tech enterprises. Wei qinxiong (2013) pointed out that the ways of subsidizing venture investment enterprises can be divided into three styles: income compensation, loss compensation and fixed income compensation [14]. In our country, for example, the scientific SMEs fund which is established by the ministry of finance and ministry of science and technology takes some important measures, such as risk subsidies, investment protection and phase participation of equity. By the end of 2012, this fund received total fiscal funds of 2.059 billion.

\subsection{Construction of Investment Environment}

In addition to the above measures, the government should also improve the construction of investment environment, so as to ensure the smooth and effective financing of High-tech SMEs. There are two important aspects among the infrastructure construction: One is the credit system; The other is the exit channels for venture investment institutions.

According to the above, there are three explanations for the difficulty of High-tech SMEs' financing, and the information asymmetry is one of them. It will effectively weaken the information asymmetry between invertors (venture investment institutions) and High-tech SMEs by improving the credit system or establishing the information service platform for High-tech SMEs, thus reducing the possibility of moral hazard and adverse selection. As a result, the fund supply for High-tech SMEs will increase.

In addition, as venture investment institutions, their final goal is not holding the equity of High-tech SMEs for a long time as a long-term shareholder. They try their best efforts to invest in the High-tech SMEs who have excellent prospects for development or those who are undervalued. For example, they will fulfill due diligence carefully and conduct detailed screening to get the High-tech SMEs of high quality. Based on their long-term accumulation of experience, they can provide value-added services for the High-tech SMEs to help these enterprises' rapid growth. When these enterprises grow to the stage where they can be listed or conduct the mergers and acquisitions, venture investment institutions will choose to exit these enterprises through IPOs, mergers and acquisitions and other ways of equity transferring. Exiting and getting the gains is venture investment institutions' final goal. Therefore, establishing sound exit mechanism is helpful to promote the development of venture investment institutions.

\section{The Government Failure of Governmental Intervention in the Financing of High-Tech SMEs}

Considering the market failure of the financing of High-tech SMEs, it is necessary for the Governmental intervention. However, the Governmental intervention is not always successful. Governmental venture investment funds are more successful and promote economic growth in some countries, such as Australia, Israel and the United States. In contrast, this kind of fund in some countries has a negative effect, such as Britain and Canada. 
Cumming \& MacIntosh (2006) confirmed that the LSVCC fund of Canada significantly reduced the total supply of venture investment funds [15]. This gives enough proof to the fact that there exit some shortcomings when the government intervene in the financing of High-tech SMEs. The following four aspects are included.

\subsection{The Lack of Professionalism about the Managers}

First of all, the managers of state-owned venture investment institutions are appointed by the government. They are not the owner of the state-owned funds and they have no the residual claim for the profits, so there is no enough incentive for the managers to work hard. Secondly, the managers themselves don't master the professional knowledge about venture investment. As we know, venture investment is a high-risk industry, which put forward a high demand of professional knowledge for the practitioners. Therefore, the managers of state-owned venture funds who were government official previously don't have the corresponding management skills of investment.

\subsection{The Crowding out}

Existing research shows that in the market of venture investment, government venture investment funds should be a supplement to the private investment fund, instead of a competitive force [16] [17]. Cumming \& MacIntosh (2006) confirmed that the Canadian tax incentives to the LSVCC fund lead to a significant crowding out, and significantly reduced the total supply of venture investment funds [15]. Cumming \& Johan (2008) found that the investment of PSF project crowded out the investment of IIF project at different stages of venture capital investment projects in Australia [18].

\subsection{Rent-Seeking}

No matter what kind of intervention of the government, they are likely to be used by certain groups, resulting in a distorting [19] [20]. Because participation of government, enterprises may choose to increase profit directly through bribery to the government [21]. Considering the political achievements, the government may choose to fund those enterprises who conduct a more successful business, regardless of whether they need the money or not [22] [23], thereby weakening the effect of government policy which aims at easing the market failure. For financial institutions, they make scarcity by rent-seeking, thus distorting the market price of fund and furthermore leading to the misallocation of resource, and this results in ineffectiveness when using financial resource.

\subsection{Policy Is Merely a Formality}

Take our county's tax incentives for example. According to the data of a survey in 2012, 50.5\% of the venture investment institutions bears a tax burden of less than $10 \%$; $24.6 \%$ of them bears a tax burden of $10 \%-20 \%$; $16.1 \%$ of them bears a tax burden of $20 \%-30 \%$; $8.7 \%$ of them bears a heavy tax burden of more than $30 \%$. Comparing it with 2011, we find that there is a increase in tax burden of the overall venture capital industry, the share of venture investment institutions who bear a heavy tax burden increased, and the policy of tax incentives has not been implemented effectively in some areas.

\section{Advice on Policy}

To maximize the effectiveness of governmental interventions, avoid policy distortions and thus to effectively alleviate the financing difficulty of High-tech SMEs, this article puts forward the following Suggestions:

\subsection{Government Funds' Investing to the Early Stage}

Considering the crowding out of government funds, the governments should trade off between the degree of the market failure and the crowding out when they are making the decision about the investment of venture fund. In fact for the High-tech SMEs, when they are in different stages of their life cycle, the degree of the market failure they face is different. High-tech SMEs in the stage of seed period and start-up period face serious market failure, and besides the angel investment, there are few other investment funds for them; Usually, in extended period, growth period and mature period of High-tech SMEs, market failure is not too serious. Therefore, more government funds should be invested into the seed period and start-up period, and less funds into mature period to 
avoid crowding out.

\subsection{Placing the Position as the Role of Government Guidance}

Many scholars think that the government should not act as a dominant role in the market of VC [24] [25]. Therefore, the government should place his position as the role of government-guided funds, and cooperate with the private venture investment institutions, which can help effectively to alleviate some important problems, such as the lack of professional knowledge on the government staff and low efficiency of the government funds. As a result, the difficulty of High-tech SMEs' financing can be alleviated to some extent, thus promoting the healthy development of High-tech SMEs.

\subsection{Implementing Policies Effectively, Not Just Formulating}

Formulating correct and effective policies of governmental intervention is the premise to alleviate the problem of market failure, but the key is the effective implementation of these policies. Based on the fact that the many policies are merely a formality, the government should vigorously promote the implement of policies, improve the mechanism of policy implementation and optimize the environment of policy implementation. Only the policy is executed effectively, can the effect of governmental intervention be maximized in solving the problem of High-tech SMEs' financing.

\section{References}

[1] Cosh, A. and Hughes, A. (2003) Enterprise Challenged: Policy and Performance in the British SME Sector 1999-2002. ESRC Centre for Business Research.

[2] Mason, C.M. (2009) Public Policy Support for the Informal Venture Capital Market in Europe: A Critical Review. International Small Business Journal, 27, 536-556. http://dx.doi.org/10.1177/0266242609338754

[3] Gompers, P.A. and Lerner, J. (1999) The Venture Capital Cycle. MIT Press, Cambridge.

[4] Gompers, P.A. and Lerner, J. (2001) The Venture Capital Revolution. Journal of Economic Perspectives, 15, $145-168$. http://dx.doi.org/10.1257/jep.15.2.145

[5] Gompers, P.A. and Lerner, J. (2001) The Money of Invention: How Venture Capital Creates New Wealth. Harvard Business School Press.

[6] Jensen, M.C. and Meckling, W.H. (1976) Theory of the Firm: 195 Managerial Behavior, Agency Costs and Ownership Structure. Journal of Financial Economics, 3, 305-360. http://dx.doi.org/10.1016/0304-405X(76)90026-X

[7] Aghion, P. and Bolton, P. (1992) An Incomplete Contracts Approach to Financial Contracting. Review of Economic Studies, 59, 473-494. http://dx.doi.org/10.2307/2297860

[8] Arrow, K. (1962) Economic Welfare and the Allocation of Resources for Invention. Princeton University Press, 609626.

[9] Cumming, D.J. and MacIntosh, J.G. (2004) Canadian Labour Sponsored Venture Capital Corporations: Bane or Boon? In: Ginsberg, A. and Hasan, I., Eds., New Venture Investment: Choices and Consequences, Elsevier Science Academic Press, 169-200.

[10] Cochrane, J.H. (2005) The Risk and Return of Venture Capital. Journal of Financial Economics, 75, 3-52.

[11] Grubert, H. and Mutti, J. (1991) Taxes, Tariffs and Transfer Pricing in Multinational Corporate Decision Making. The Review of Economics and Statistics, 13, 285-293. http://dx.doi.org/10.2307/2109519

[12] Swenson, D.L. (1994) The Impact of US Tax Reform on Foreign Direct Investment in the United State. Journal of Public Economics, 54, 243-266.

[13] Hines Jr., J.R. (1996) Altered States: Taxes and the Location of Foreign Direct Investment in America. National Bureau of Economic Research.

[14] Wei, Q.X. (2013) Government's Compensation Mechanisms and Their Incentive Effects under FOF Institutio. System Engineering-Theory \& Practice, 33, 1926-1933.

[15] Cumming, D.J. and MacIntosh, J.G. (2006) Crowding out Private Equity: Canadian Evidence. Journal of Business Venturing, 21, 569-609. http://dx.doi.org/10.1016/j.jbusvent.2005.06.002

[16] Lerner, J. (1999) The Government as Venture Capitalist: The Long-Run Effects of the SBIR Program. Journal of Business, 72, 285-318.

[17] Lerner, J. (2002) When Bureaucrats Meet Entrepreneurs: The Design of Effective Public Venture Capital Programmes. 
Economic Journal, 112, 73-84. http://dx.doi.org/10.1111/1468-0297.00684

[18] Cumming, D.J. and Johan, S.A. (2008) Pre-Seed Government Venture Capital Funds. Journal of International Entrepreneurship, 7, 26-56. http://dx.doi.org/10.1007/s10843-008-0030-x

[19] Peltzman, S. (1976) Toward a More General Theory of Regulation. Journal of Law and Economics, 19, 211-240. http://dx.doi.org/10.1086/466865

[20] Becker, G.S. (1983) A Theory of Competition among Pressure Groups for Political Influence. The Quarterly Journal of Economics, 98, 371-400. http://dx.doi.org/10.2307/1886017

[21] Eisinger, P.K. (1988) The Rise of the Entrepreneurial State: State and Local Economic Development Policy in the United States. University of Wisconsin Press.

[22] Cohen, L. and Noll, R. (1991) The Technology Pork Barrel. Cohen Technology Pork Barrel, Brookings Institution, Washington DC.

[23] Wallsten, S.J. (2000) The Effects of Government-Industry R\&D Programs on Private R\&D: The Case of the Small Business Innovation Research Program. The RAND Journal of Economics, 31, 82-100. http://dx.doi.org/10.2307/2601030

[24] Keuschnigg, C. (2003) Public Policy and Venture Capital Backed Innovation. CESifo Working Paper, 1066.

[25] Keuschnigg, C. and Nielsen, S.B. (2001) Public Policy for Venture Capital. International Tax and Public Finance, 8, 557-572. http://dx.doi.org/10.1023/A:1011251920041 